\title{
Tilapia - An Excellent Candidate Species for World Aquaculture: A Review
}

\author{
E. Prabu ${ }^{1 *}$, C. B. T. Rajagopalsamy ${ }^{2}$, B. Ahilan ${ }^{1}$, \\ I. Jegan Michael Andro Jeevagan ${ }^{1}$ and M. Renuhadevi ${ }^{1}$ \\ ${ }^{1}$ Department of Aquaculture, Fisheries College and Research Institute, Tamil Nadu Fisheries \\ University, Thoothukudi - 628008, Tamil Nadu, India. \\ ${ }^{2}$ Department of Fish Nutrition and Feed Technology, Fisheries College and Research Institute, \\ Tamil Nadu Fisheries University, Thoothukudi - 628008, Tamil Nadu, India.
}

Authors' contributions

This work was carried out in collaboration among all authors. All authors read and approved the final manuscript.

Article Information

DOI: 10.9734/ARRB/2019/v31i330052

Editor(s):

(1) Dr. Layla Omran Elmajdoub, Department of Zoology, Faculty of Science, Misurata University, Misurata, Libya.

(2) Dr. George Perry, Dean and Professor of Biology, University of Texas at San Antonio, USA.

Reviewers:

(1) Wagner Loyola, Brazil

(2) Yuzine B. Esa, Universiti Putra Malaysia, Malaysia. Complete Peer review History: http://www.sdiarticle3.com/review-history/35935

Review Article

Received 17 June 2017

Accepted 23 August 2017

Published 29 March 2019

\begin{abstract}
Aquaculture is currently playing, and will continue to play, a big part in boosting global fish production and in meeting the rising demand of fishery products. Capture fisheries production has levelled off and is no longer considered capable of sustaining the supply of fisheries products needed to meet the growing global demand. Tilapia is the common name for several species of cichlid fish inhabiting freshwater streams, ponds, rivers and lakes and less commonly in brackish water. Considered as an invasive species, tilapias are now of increasing importance in Aquaculture. Tilapia is the second most farmed fish world-wide and its production has quadrupled over the past decade because of its suitability for aquaculture, marketability and stable market prices. Native to Africa and Middle East, tilapias were introduced into over 90 countries for aquaculture and fisheries. Tilapia continued its rapid increase in global production. Recent production figures reported by various sources, our global production estimate for 2015 is $5,576,800 \mathrm{mt}$. Tilapias are now one of the most widely introduced fish globally that has clearly emerged as a very promising group in aquaculture.
\end{abstract}


Keywords: Tilapia; aquaculture; cage; pond; raceway; biofloc.

\section{INTRODUCTION}

Aquaculture production has increased steadily in recent years and is the fastest growing food production sector and has become a valuable component of national development and poverty reduction plans in many areas of the world [1]. Aquaculture is one of the fastest growing sectors of the global livestock production [2]. Approximately $40 \%$ of fish from aquaculture is originated from tilapia production [3]. Aquaculture is currently playing, and will continue to play, a big part in boosting global fish production and in meeting the rising demand of fishery products.

Global inland waters capture production reached 11.6 million tonnes in 2012. Total farmed food fish production has increased from $50 \%$ in 1980 to $63 \%$ in 2012. In the world scenario, 15 countries produced $92.7 \%$ of all farmed food fish in 2012. India, Bangladesh, Egypt, Myanmar and Brazil depend mainly on inland aquaculture of finfish while their potential for mariculture production of finfish remains largely untapped [4].

\section{TILAPIA}

Capture fisheries production has levelled off and is no longer considered capable of sustaining the supply of fisheries products needed to meet the growing global demand [5]. Aquaculture, especially of tilapias, has the potential to play a leading role in the fight against food insecurity, malnutrition, and poverty in Africa [6]. Tilapia is the common name for several species of cichlid fish inhabiting freshwater streams, ponds, rivers and lakes and less commonly in brackish water. Considered as an invasive species, tilapias are now of increasing importance in Aquaculture. Tilapia is the second most farmed fish world-wide and its production has quadrupled over the past decade because of its suitability for aquaculture, marketability and stable market prices [7].

The Nile tilapia, Oreochromis niloticus is considered as one of the most important species of fish in tropical and sub-tropical aquaculture [4]. It serves as an important sources of animal protein and income throughout the world [8]. Tilapia can grow and reproduce facing a wide range of environmental conditions and tolerate stress induced by handling [9]. The mono-sex male population of tilapia are well recognized for increased production potential and low management requirements [10]. Today, tilapia has become the shining star of aquaculture and also popularly known as 'aquatic chicken' and the rate of consumption has increased across the globe [11]. Annual global production of cultured tilapia has increased continuously in recent years [9].

Native to Africa and Middle East, tilapias were introduced into some 90 countries for aquaculture and fisheries, through Pan-African transplants $[12,13]$ during the $20^{\text {th }}$ century. Presently, a major part of the global tilapia production is outside the fish's native ranges. Tilapias are now grown commercially in almost 10 countries and have become one of the most important food fishes in the world. It is the second most important farmed fish species after the carps.

Unlike most other finfish species, tilapias are extremely hardy fish equally adaptable to a range of culture systems such as low density pond systems, cage culture systems, raceway systems and super-intensive culture systems under a wide range of environmental conditions. Due to its easiness of breeding and farming, low protein requirement and ability to assimilate plant protein, it became the species of interest among the resource poor especially in rural areas. This fish is also popular and prized in many Asian countries, including the Philippines and Indonesia, where local people adopted it as a vital part of the national cuisine and as a native species of their country [14]. During the 1970's, this fish inspired the International Development Agencies to name it as "Aquatic Chicken" and twenty years later as "fish of the 1990's". Presently it is considered as "Food fish of the $21^{\text {st }}$ Century" $[15,16]$.

Asian countries are the major producers as well as the consumers of tilapia. World aquaculture production of Oreochromis niloticus alone presently stands at nearly 3.2 million tons with china being the major producer, contributing over one third of the total global production. Tilapias are also widely farmed in countries such as Egypt, Indonesia, Thailand, Philippines, Brazil, Bangladesh, Vietnam, Columbia and Malaysia. An international collaborative project to improve the genetic performance of farmed Nile tilapia (Oreochromis niloticus) was initiated at the Bureau of Fisheries and Aquatic Resources/Freshwater Aquaculture Center (BFAR/FAC) facilities in Muñoz, Philippines in $1988[17,13]$. 


\section{COMMERCIALLY SPECIES OF TILAPIA}

IMPORTANT

Thys [18] described 77 species (besides a number of sub-species) of tilapia, and Jhingran \& Gopalakrishnan [19] listed 22 species that have been used in experimental or production scale fish culture. The major cultivable species of tilapia are Oreochromis niloticus (Nile tilapia), Oreochromis mossambicus, (Mozambique tilapia), Oreochromis aureus (Blue tilapia), Oreochromis hornorum (Zanzibar tilapia) and Oreochromis hybrids (Red tilapia). Nile tilapia is the predominant cultured species worldwide. More than 90 percent of all commercially farmed tilapia outside Africa are Nile tilapia. The hybrid "red" tilapia has also become increasingly popular for farming because of its similar appearance to the marine red snapper that gives it high market value. The original red tilapias were genetic mutants. Tilapia farming has gained its popularity in China, Bangladesh, Indonesia, Laos, Malaysia, Taiwan, Philippines and Vietnam. People do not treat it as exotic fish, instead regard as very important source of fish quality animal protein and income. The natural distribution of tilapia is restricted to Africa, Jordan, and Israel, where 112 species and subspecies of the genera Oreochromis, Sarotherodon, and Tilapia have been identified $[10,20]$.

\section{AQUACULTURE OF TILAPIA}

The farming of tilapias especially Oreochromis niloticus (Nile tilapia) in its natural form is believed to have originated more than 4000 years ago from Egypt. From the borders of their native, this versatile group of fish has travelled far, reaching every continent except Antarctica. Tilapias are now being cultured all over the world and in fact they are more common in Asia than in their African home land [14,21]. Most of the tilapia-culture practices have been restricted to tropical and sub-tropical regions of the world [22, 23].

In 1978, Nile tilapia was introduced to China, which leads the world in tilapia production and consistently produced more than half of the global production in every year from 1992 to 2003. The uncontrolled breeding of tilapia in ponds, which led to excessive recruitment, stunting and a low percentage of marketablesized fish, dampened the initial enthusiasm for tilapia as a food fish. The development of hormonal sex-reversal techniques in the 1970s represented a major breakthrough that resulted in the production of male monosex populations to be raised to uniform, marketable sizes. Historically and from a social standpoint, the most important use of tilapia has been production for home consumption, with millions of smallscale fish farmers in more than 100 countries supplementing their diets with tilapia [24].

In monosex culture, males are preferred because they have a faster growth rate than females. In addition, research on nutrition and culture systems, along with market development and processing advances, led to rapid expansion of the industry in the mid-1980s. Several species of tilapia are cultured commercially, but Nile tilapia Oreochromis niloticus the predominant cultured species worldwide [4].

\section{PREFERENCE OF TILAPIA FOR AQUACULTURE}

Tilapia is the second most farmed fish in the world after carps. The Global market for tilapia is growing at the rate of $10-12 \%$ per year. More commonly, fresh tilapia also is provided for sale either at the farm gate or in local markets. However, tilapias have grown in importance from being just a low-cost, high-protein food fish ("aquatic chicken" [25]) employed by development agencies to feed the poor in the world's rural areas, to a highly-domesticated "livestock" with annual sales amounting to over $\$ 2$ billion globally $[2,24]$. The major reasons for its popularity among aqua farmers are listed below:

$\checkmark$ Feeding habits (Herbivore / Omnivore, Low trophic level feeder)

$\checkmark$ Algae, bacteria and detritus (bioflocs) are important food sources

$\checkmark$ Prepared feeds are mostly grains and agriculture by-products

$\checkmark$ Fast growth rate

$\checkmark$ Easy adaptability to different conditions including high stocking densities

$\checkmark$ Highly disease resistant and tolerant of poor water quality

$\checkmark$ Antibiotics and chemicals are not needed for commercial farming

$\checkmark$ Prolific breeders, easy breeding in captivity

$\checkmark$ Fry do not pass through a planktonic phase, in its life cycle

$\checkmark$ Fry consume formulated feed immediately after yolk-sac absorption, no live feed such as algae, rotifer and artemia is necessary

$\checkmark$ Low production costs 
$\checkmark \quad$ White flesh and meat suitable for a wide variety of value added forms

$\checkmark$ Good market demand and readily acceptable by consumer.

In terms of economic importance, tilapia surpassed the salmonids in 2004, and they are expected to eventually equal the carps [24]. The tilapias have been referred to as the "most important global whitefish commodity" [26].

\section{AQUACULTURE OF TILAPIA IN INDIA}

Tilapias are one of the most widely introduced fish globally that has clearly emerged as a very promising group in aquaculture. Oreochromis mossambicus was the first tilapia species to be taken up for large scale aquaculture, followed by Oreochromis niloticus, Oreochromis aureus and Tilapia rendalli. Today Oreochromis niloticus contributes more than $80 \%$ of global tilapia production by aquaculture.

In India, Oreochromis mossambicus was introduced from Srilanka in 1952 and thereafter stocked in several reservoirs of southern India for production enhancement [27]. Tilapia now forms a part of fish fauna in the Godavari, Krishna, Cauvery, Yamuna and Ganga Rivers [28].

Oreochromis niloticus was probably introduced unofficially in West Bengal in the late 1970s or early 1980s and in Andhra Pradesh during the late $80 \mathrm{~s}$. Through it was also popularized in the states of Kerala and Tamil Nadu, the overall experience with the species had not been encouraging as the fish turned out to be a prolific breeder, leading to over population and stunted growth in both aquaculture ponds and reservoirs. Tilapia is also reported to have displaced and virtually eliminated a number of species from some reservoirs of India. Subsequently, the fish was abandoned as candidate species for aquaculture in the country [29].

Today Oreochromis niloticus is being cultured in some parts of the country mainly as a live feed for carnivorous fish such as seabass and forms a fishery in a few reservoirs and water bodies of Kerala, Tamil Nadu and Andhra Pradesh. Large quantities of small sized tilapia are also harvested and used as feed for seabass and mud crab aquaculture. Unlike Oreochromis mossambicus, growth performance of Oreochromis niloticus in the ponds and reservoirs of India is much better. Considering that Oreochromis niloticus, is the most widely cultured tilapia species globally and in view if the immense aquaculture possibilities in India and need for enhancing production in freshwater farming systems, the Ministry of Agriculture, Government of India formally issued guidelines for responsible farming of tilapia in India during December 2011.

\section{GENETICALLY IMPROVED FARMED TILAPIA STRAIN}

The GIFT strain was developed by International Centre for Living Aquatic Resources Management (ICLARM) through several generation of selection from base population involving 8 different strains of Nile tilapia Oreochromis niloticus [29].

A ten year collaborative research project (1988 to 1997) widely known as 'Genetic Improvement of Farmed Tilapias (GIFT)' was conducted by the World Fish Center in cooperation with AKVAFORSK (The Institute of Aquaculture Research in Norway), and a number of national research institutions in the Philippines: the National Freshwater Fisheries Technology Research Center of the Bureau of Fisheries and Aquatic Resources, the freshwater Aquaculture Center of the Central Luzon State University, and the Marine Science Institute of the University of the Philippines. The GIFT project demonstrated the potential of using selective breeding to genetically enhance the production of the GIFT strain was improved by more than 80 percent compared with the base population.

A complete diallel cross experiment with all eight strains was then carried out to study possible heterosis effects on growth performance in seven different farming environments [30]. It was concluded that genotype by environment interactions and non-additive gene effects were of minor importance for growth performance. Consequently, it was decided to form a synthetic population composed of three and four way crossed individuals involving all eight founder strains, and genetic parameters for growth performance in seven different farming environments were estimated [29].

GIFT technology includes a number of different and complementary tools to produce and test tilapia of known ancestry, to statistically analyse collected grow-out data, and finally, to estimate breeding values for each individual, based on the performance of the breeding candidates themselves and their relatives in the population. 
The GIFT project resulted in a faster-growing, synthetic aquaculture stock of Nile tilapia $[31,32,33]$ that has later been an important genetic source for a variety of public and private genetic improvement and/or dissemination programs $[34,35]$.

Aquaculture must grow rapidly as an alternative to the declining capture fisheries in the world. Genetically improved stock, such as the GIFT Strain, has an important role to play in increasing aquaculture production in developing countries. However, in some cases, the introduction of already improved strains may not be possible or desirable due to health or bio-diversity considerations. In such cases it is important that, as an alternative, the technology for genetic enhancement of fish be transferred and applied to native species.

Several genetic techniques (e.g. selective breeding, cross-breeding, chromosome manipulation, $Y Y$ - male technology) are available to enhance the productivity of aquaculture species, including tilapias. However, with the exception of selective breeding, these technologies only result in a once-off gain, and not in continued improvement. A continuous improvement of relevant traits requires a welldesigned selective breeding program where the pedigree of brood fish is monitored to increase the accuracy of selection and to restrict inbreeding.

\section{TILAPIA CULTURE SYSTEMS}

Tilapia farming ranges from a rural subsistence (extensive, low input practices, non-commercial and for household consumption) to a largescale (capital intensive, commercial purpose and market driven) level, depending on the intensity of management employed. The following provide the details of the culture practices used globally.

\subsection{Ponds}

Most of the pond-based tilapia farmers in Bangladesh, China, Taiwan, Thailand and Vietnam use the polyculture system while in the Philippines, most farmers grow tilapias under the monoculture system. Culture methods followed in these countries vary depending on nature of farmland and farmers' capacity to invest. Pond culture of tilapia is conducted with a variety of inputs such as agricultural by-products (brans, oil cakes, vegetation and manures), inorganic fertilizers and feed. Annual fish yields using tilapia in polyculture with carps, high levels of agricultural by-products and good stock management can reach or exceed 5 tonnes/ha.In monoculture tilapia systems, animal manures provide nutrients that stimulate the growth of protein-rich phytoplankton, which is consumed by filter feeding Nile tilapia. The nutrient content of manures varies. Water buffalo manure has much lower nutrient levels compared to duck and chicken manure. Obtaining sufficient nutrient levels from manures poses a danger of oxygen depletion from excessive loading of organic matter. Therefore, a combination of manures with inorganic fertilizers is used in low-input production systems. In Thailand, applying chicken manure weekly at 200-250 kg DM (dry matter)/ha and supplementing it with urea and triple super phosphate (TSP) at $28 \mathrm{~kg} \mathrm{~N} / \mathrm{ha} /$ week and $7 \mathrm{~kg} \mathrm{P} / \mathrm{ha} /$ week produces a net harvest 3.44.5 tonnes/ha in 150 days at a stocking rate of 3 $\mathrm{fish} / \mathrm{m}^{2}$ or an extrapolated net annual yield of 811 tonnes/ha.

\subsection{Cages}

The culture of Nile tilapia at high densities in floating cages is practiced in large lakes and reservoirs of several countries including China, Indonesia, Mexico, Honduras, Colombia, and Brazil. Mesh size has a significant impact on production and should be $1.9 \mathrm{~cm}$ or greater to maintain free circulation of water. Cage culture offers several important advantages. The breeding cycle of tilapia is disrupted in cages, and therefore mixed-sex populations can be reared in cages without the problems of recruitment and stunting. Eggs fall through the cage bottom or do not develop if they are fertilized. Other advantages include:

$\checkmark \quad$ Use of water bodies that cannot be drained or seined and would otherwise not be suitable for aquaculture.

$\checkmark$ Flexibility of management with multiple production units.

$\checkmark \quad$ Ease and low cost of harvesting.

$\checkmark \quad$ Close observation of fish feeding response and health.

$\checkmark$ Relatively low capital investment compared to other culture techniques. 


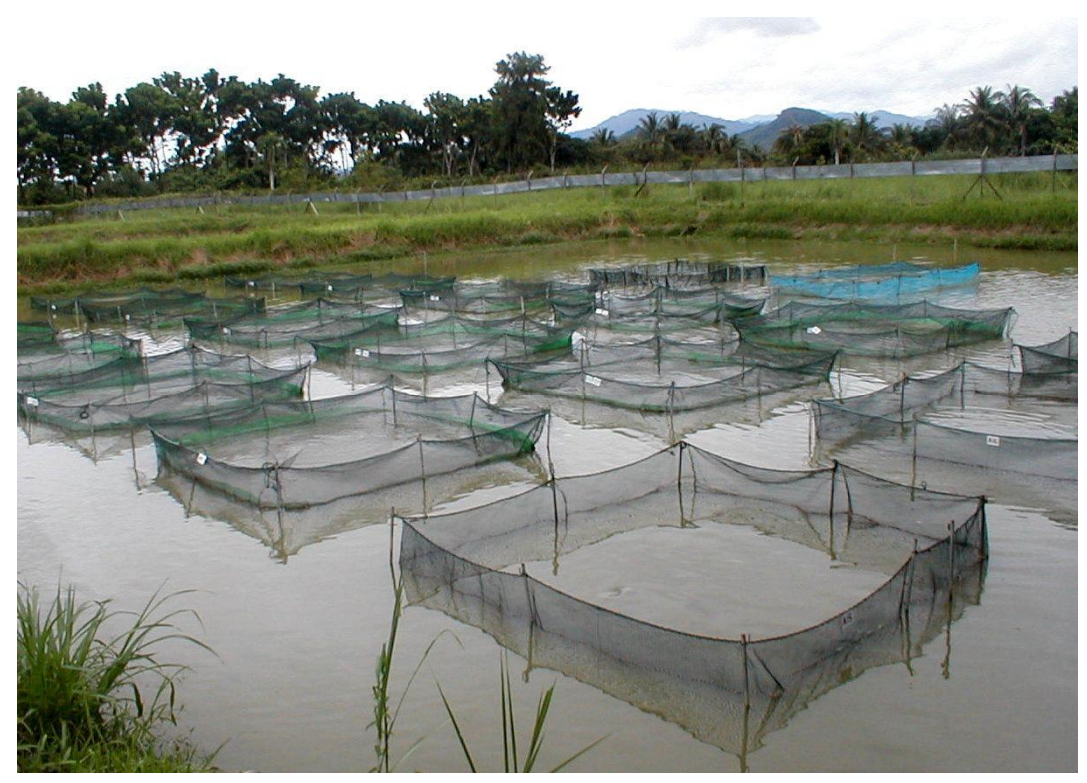

Fig. 1. Pond culture of tilapia

In Asia, the Philippines was the pioneer for cage culture in lakes and reservoirs in the region and practices semi intensive and intensive farming [36]. It was reported that, the country's cages in 2000 ha of water produced a total of $33,067 \mathrm{mt}$ of O. niloticus. The average yield of $540 \mathrm{~kg} / 100 \mathrm{~m} 2$ cage is attained with $O$. niloticus (mean weight of $175 \mathrm{~g}$ each) after 5 months of rearing fingerlings.

\subsection{Raceways and Tanks}

Tanks and raceways can only be a good alternative to pond or cage culture if sufficient water or land is not available and economics are favourable. Unlike ponds, it is easier to manage the stocks and exert a relatively high degree of environmental control over water quality parameters. However, tank and raceway culture requires higher investment due to increased construction and production costs (complete commercial diet, aeration, recirculating system). The farming of tilapias in tanks/raceways also needs close and constant attention due to higher risk of major fish mortality caused by disease outbreak and mechanical or electrical failure.

In Asia, intensive culture of tilapias in concrete tanks is practiced in Taiwan, Malaysia and Philippines. Taiwan is the pioneer in the region for the intensive culture of tilapia in concrete tanks and produces over 50,000 tons annually, most operations being small to medium level operations [37]. Red tilapias are cultured in 100 $\mathrm{m} 2$ octagonal tanks with water change and aeration, and with fish weighing $100-200 \mathrm{~g}$ and densities of $50-100 / \mathrm{m} 2$. With $3-4$ times of feeding per day using commercial feeds and automatic feeders, yields of 3-4mt/tank/cycle of 3- 4 months are obtained with fish weighing $600 \mathrm{~g}$ on the average, survival of $90 \%$ or higher and feed conversions of 1.2-1.4 [36]. Although raceways/tank culture of tilapias is not a common practice in Africa, it is also used in some areas.

The maximum tilapia density in raceways ranges from $160-185 \mathrm{~kg} / \mathrm{m}^{3}$, and maximum loading ranges from $1.2-1.5 \mathrm{~kg} / \mathrm{litre} / \mathrm{min}$. A common production level in raceways is $10 \mathrm{~kg} / \mathrm{m}^{3} /$ month, as water supplies are often insufficient to attain maximum rates. Production levels are considerably lower in tanks with limited water exchange, but water use efficiency is much higher in these systems.

\section{BIOFLOC TECHNOLOGY - AN EMERGING TREND IN TILAPIA CULTURE}

In intensive aquaculture business, the highest production cost goes to feeding the organisms, further around $60 \%$ of it is wasted by the organisms, which causes phosphorus, carbon, nitrogen to prevail in water as suspended matter or dissolved chemicals and are expelled from the system by gasification or water change polluting other natural water bodies and near-by soils producing economic losses to producers [38]. To reduce the environmental damages caused by 
aquaculture, the alternative technology available is to optimize production with the usage of the "Biofloc" Technology (BFT).

Biofloc technology is a technique of enhancing water quality through the addition of extra carbon to the aquaculture system, through an external carbon source or elevated carbon content of the feed [39]. Biofloc technology is a novel farming technique that efficiently manages water quality parameters in aquaculture through balancing carbon and nitrogen in the system. Currently, biofloc technology has received considerable attention because of its potential to generate high production, feed protein recycling, water quality management and a possible alternative measure for disease control $[40,41]$.

With almost seven billion people on earth, the demand for aquatic food carries on to increase and hence, expansion and intensification of aquaculture production are highly required. The prime goal of aquaculture expansion must be to produce more aquaculture products without significantly increasing the usage of the basic natural resources of water and land [41]. The second goal is to develop sustainable aquaculture systems that will not damage the environment [42]. The third goal is to build up systems providing an equitable cost/benefit ratio to heterotrophic bacteria occurs much more rapidly because the growth rate and microbial biomass yield per unit substrate of heterotrophs are a factor 10 higher than that of nitrifying bacteria [39]. The microbial biomass yield per unit substrate of heterotrophic bacteria is about $0.5 \mathrm{~g}$ biomass $\mathrm{C} / \mathrm{g}$ substrate $\mathrm{C}$ used [43].

Suspended growth in ponds consists of phytoplankton, bacteria, aggregates of living and dead particulate organic matter, and grazers of the bacteria [39] Typical flocs are irregular by shape, have a broad distribution of particle size, are fine, easily compressible, highly porous (up to more than $99 \%$ porosity) and are permeable to fluids [44].

\subsection{The use of Bioflocs as a Feed for Aquaculture Species}

In addition to the growing demand for seafood for human consumption, the demand for aquatic products used by the industrial sector for conversion into fishmeal and fish oil products also increases [45]. Fishmeal and fish oil are used as feed for other human food supply systems, such as poultry, pigs and aquaculture.
Hitherto, part of the aquaculture production relies on wild fish harvests, as fishmeal and fish oil are essential elements of the diet of many aquaculture species, both carnivorous and herbivorous fish and shrimp [46]. About 5-6 million tonnes of low-value/trash fish are used as direct feed in aquaculture worldwide either provided without processing or as part of farmmade feeds [47]. FAO [47] reported that the total amount of fishmeal and fish oil used in aquafeeds is estimated to have grown more than threefold between 1992 and 2006, from 0.96 million tonnes to 3.06 million tonnes and from 0.23 million tonnes to 0.78 million tonnes, respectively. For the 10 types of fish most regularly farmed, a mean of $1.9 \mathrm{~kg}$ of wild fish is required for every kilogram of fish produced [40]. In terms of fishmeal, many intensive and semiintensive aquaculture systems use 2 to 5 times more fish protein to feed the farmed species than is supplied by the farmed product [42]. Therefore, research in recent times has focused on the development of feed substitution strategies with a minimal supply of fishmeal and fish oil, which are then replaced by alternative and cheaper sources of protein such as plant proteins [46]. In contrast to intensive and semi intensive systems, extensive and traditional systems already use little or no fishmeal, and farmers often supply nutrient-rich materials to the water to enhance growth of algae and other indigenous organisms on which the fish can feed [42]. This inspired researchers to develop the biofloc technology, which is also applicable to intensive and semiintensive systems. With biofloc technology, where nitrogenous waste generated by the cultivated organisms is converted into bacterial biomass (containing protein), in situ feed production is stimulated through the addition of an external carbon source [48].

Although bioflocs show an adequate protein, lipid, carbohydrate and ash content for use as an aquaculture feed [49], more research is needed on their amino acid and fatty acid composition. Now, fishmeal and fish oil supply essential amino acids (such as lysine and methionine) that are deficient in plant proteins and fatty acids (eicosapentanoic acid and docosahexanoic acid) not found in vegetable oils [42]. Herbivorous, omnivorous and carnivorous finfish all necessitate about the same amount of dietary protein per unit weight, but herbivorous and omnivorous species utilize plant-based proteins and oils better and they require minimal quantities of fishmeal to supply essential amino acids [42]. However, compound feeds for 
omnivorous fish often exceed required levels [42]. On the other hand, lowering the input of wild fish required for production of farmed carnivorous fish seems not feasible at this time [42]. Concomitantly, more research is needed regarding feed replacement strategies such as using vegetable oils, meat byproducts and also biofloc technology. With biofloc technology, one also needs to consider that the choice of cultivated species should take into account their capability of dealing with high suspended solid concentrations, since this negatively affects certain fish species [46].

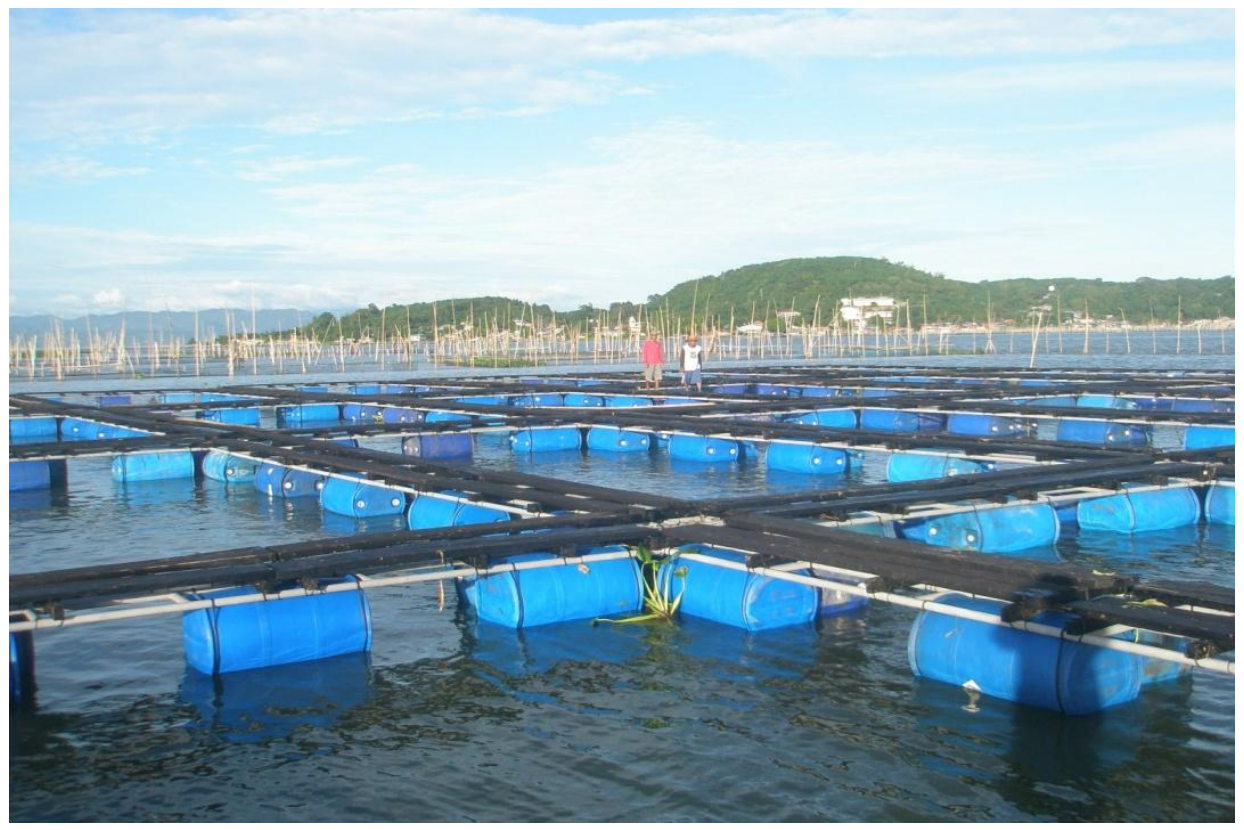

Fig. 2. Cage culture of tilapia

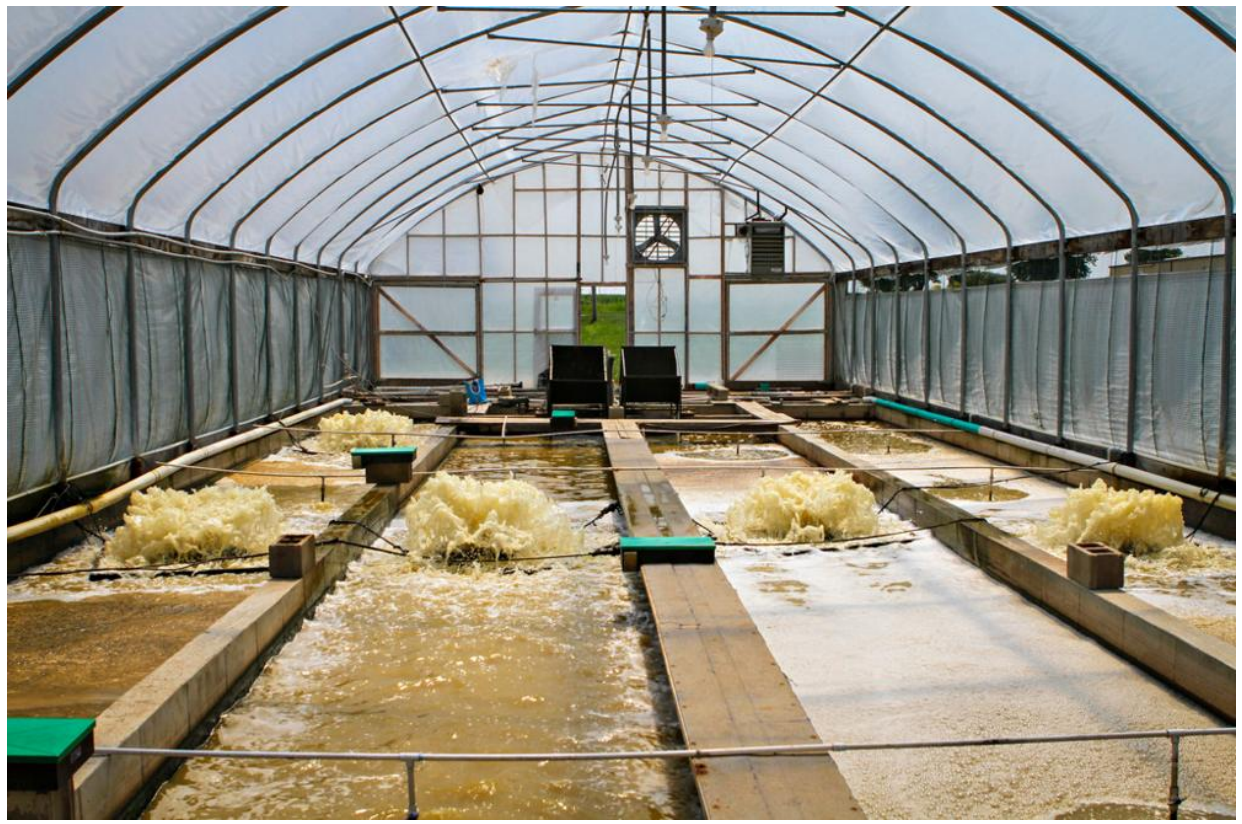

Fig. 3. Tilapia culture in raceways 


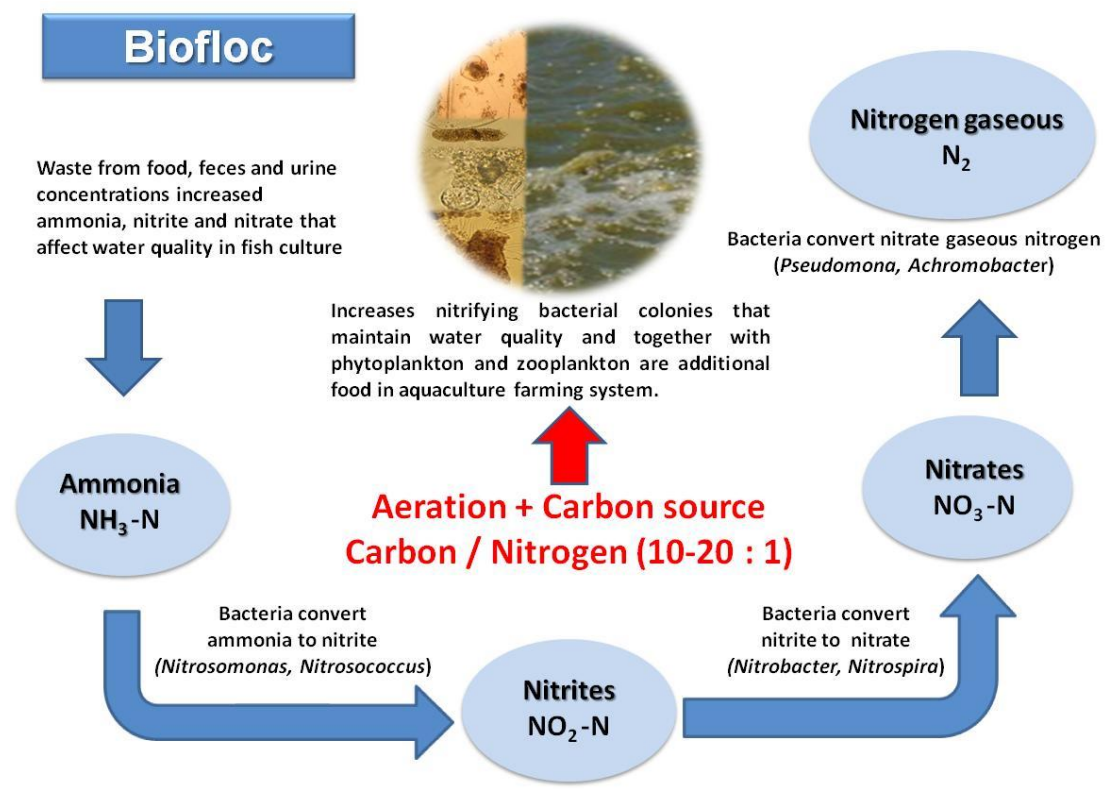

Fig. 4. The biofloc technology

Another important factor that is essential for the growth and survival of aquaculture species are vitamins. Crab [49] measured vitamin C concentrations in bioflocs ranging from 0 to 54 $\mu \mathrm{g} / \mathrm{g}$ dry matter. These values are below the required concentration for fish and shrimp. Besides vitamin $\mathrm{C}$, other vitamins such as thiamine, riboflavin, pyridoxine, pantothenic acid, nicotinic acid, biotin, folic acid, vitamin B12, inositol, choline, vitamin A, vitamin D3, vitamin E and vitamin $\mathrm{K}$, are usually not sufficiently synthesized by the cultured organism either and need to be supplied through the feed. Hence, it needs to be established to what extent bioflocs can contribute to the supply of these essential nutrients. Several studies were performed on the use of bioflocs as an in situ produced feed and they indicate that bioflocs can be taken up by aquaculture species and uptake depends on the species and feeding traits, animal size, floc size and floc density $[41,49,50]$. The giant freshwater prawn (Macrobrachium rosenbergii), white leg shrimp (Litopenaeus vannamei) and tilapia (Oreochromis niloticus $\times$ Oreochromis aureus) were all able to take up bioflocs and profit from this additional protein source. This indicates that biofloc technology is applicable to both freshwater and seawater systems, both to control water quality and to produce as an additional feed source in situ. The potential feed gain of the application of biofloc technology is estimated to be in the order of 10-20\% [51]. With this, production costs will decline considerably since food represents $40-50 \%$ of the total production costs [52].

\section{STATUS OF WORLD TILAPIA PRODUCTION}

Tilapia continued its rapid increase in global production through into 2015 . Indonesia in particular reported a large increase in production. China held relatively steady after low prices held back production in late 2014 and early 2015. In 2014 and 2015 additional expansion with more farms and more productivity in Bangladesh, Mexico, Egypt, and Brasil. With recent production figures reported by various sources, our global production estimate for 2015 is $5,576,800 \mathrm{mt}$. China continued its position as the single largest producer $(1,800,000 \mathrm{mt}$ in 2015). China's exports to the US slowed in 2015 , but increased significantly to sub-Saharan Africa and to the Middle Eastern Gulf States. Indonesia moved up to the second biggest producer with over 1,100,000 $\mathrm{mt}$ of production. Egypt dropped to the third biggest producer of tilapia in the world, even while increasing production to $800,000 \mathrm{mt}$ in 2015. Indonesia's exports did not increase that much but domestic demand grew significantly. Vietnam increased its production significantly $(150,000 \mathrm{mt})$, much of the growth based on a mix of cage culture, pond production and polyculture systems with marine shrimp to reduce virulence of the AHPNS, White Spot and various parasites. The ban of American and 
Table 1.

\begin{tabular}{|c|c|c|c|c|}
\hline Disease & Agent & Type & Syndrome & Measures \\
\hline $\begin{array}{l}\text { Motile Aeromonas } \\
\text { Septicaemia } \\
\text { (MAS) }\end{array}$ & $\begin{array}{l}\text { Aeromonas hydrophila \& related } \\
\text { species }\end{array}$ & Bacteria & $\begin{array}{l}\text { Loss of equilibrium; lethargic swimming; } \\
\text { gasping at surface; haemorrhaged or } \\
\text { inflamed fins \& skin; bulging eyes; opaque } \\
\text { corneas; swollen abdomen containing } \\
\text { cloudy or bloody fluid; chronic with low } \\
\text { daily mortality }\end{array}$ & $\begin{array}{l}\mathrm{KMnO}_{4} \text { at 2-4 } \mathrm{mg} / \text { litre indefinite } \\
\text { immersion or } 4-10 \mathrm{mg} / \mathrm{litre} \text { for } 1 \text { hour; } \\
\text { antibiotics (need 'extra-label use } \\
\text { permit' in the USA), e.g. Terramycin } \AA \\
\text { in feed at } 50 \mathrm{mg} / \mathrm{kg} \text { fish/d for } 12-14 \mathrm{~d} \text {, } \\
21 \mathrm{~d} \text { withdrawal }\end{array}$ \\
\hline Vibriosis & $\begin{array}{l}\text { Vibrio anguillarum \& other } \\
\text { species }\end{array}$ & Bacteria & $\begin{array}{l}\text { Same as MAS; caused by stress \& poor } \\
\text { water quality }\end{array}$ & Antibiotic in feed \\
\hline Columnaris & Flavobacterium columnare & Bacterium & $\begin{array}{l}\text { Frayed fins \&/or irregular whitish to grey } \\
\text { patches on skin \&/or fins; pale, necrotic } \\
\text { lesions on gills }\end{array}$ & $\begin{array}{l}\mathrm{KMnO}_{4} \text { as with } \mathrm{MAS} \text {; indefinite } \\
\text { immersion with } \mathrm{CuSO}_{4} \text { at } 0.5-3 \\
\text { mg/litre, depending on alkalinity }\end{array}$ \\
\hline Edwardsiellosis & Edwardsiella tarda & Bacterium & $\begin{array}{l}\text { Few external symptoms; bloody fluid in } \\
\text { body cavity; pale, mottled liver; swollen, } \\
\text { dark red spleen; swollen, soft kidney }\end{array}$ & Antibiotic in feed \\
\hline Streptococcosis & $\begin{array}{l}\text { Streptococcus } \\
\text { iniae \& Enterococcussp. }\end{array}$ & Bacteria & $\begin{array}{l}\text { Lethargic, erratic swimming; dark skin } \\
\text { pigmentation; exophthalmia with opacity \& } \\
\text { haemorrhage in eye; abdominal } \\
\text { distension; diffused haemorrhaging in } \\
\text { operculum, around mouth, anus \& base of } \\
\text { fins; enlarged, nearly black spleen; high } \\
\text { mortality. }\end{array}$ & $\begin{array}{l}\text { Antibiotic in feed, e.g. Erythromycin at } \\
50 \mathrm{mg} / \mathrm{kg} \text { fish/d for } 12 \mathrm{~d} \text { (requires } \\
\text { 'extra-label use' permit in the USA) }\end{array}$ \\
\hline Saprolegniosis & Saprolegnia parasitica & Fungus & $\begin{array}{l}\text { Lethargic swimming; white, grey or brown } \\
\text { colonies that resemble tufts of cotton; } \\
\text { open lesions in muscle }\end{array}$ & $\begin{array}{l}\mathrm{KMnO}_{4} \text { or } \mathrm{CuSO}_{4} \text { treatments; use } 1 \\
\mathrm{mg} / \text { /itre of } \mathrm{CuSO}_{4} \text { for every } 100 \\
\mathrm{mg} / \text { /itre alkalinity up to } 3.0 \mathrm{mg} / \mathrm{litre} \\
\mathrm{CuSO}_{4} \text {; formalin at } 25 \mathrm{mg} / \mathrm{litre} \\
\text { indefinite immersion or } 150 \mathrm{mg} / \text { litre for } \\
1 \mathrm{~h}\end{array}$ \\
\hline Ciliates & $\begin{array}{l}\text { Ichthyophthirius } \\
\text { multifiliis; Trichodina \& others }\end{array}$ & $\begin{array}{l}\text { Protozoan } \\
\text { parasite }\end{array}$ & Occurs on gills or skin & $\mathrm{KMnO}_{4}, \mathrm{CuSO}_{4}$ or formalin treatments \\
\hline $\begin{array}{l}\text { Monogenetic } \\
\text { trematodes }\end{array}$ & $\begin{array}{l}\text { Dactylogyrusspp.; Gyrodactyluss } \\
\text { pp. }\end{array}$ & $\begin{array}{l}\text { Protozoan } \\
\text { parasite }\end{array}$ & Occurs on body surface, fins or gills & Same as for ciliates \\
\hline
\end{tabular}




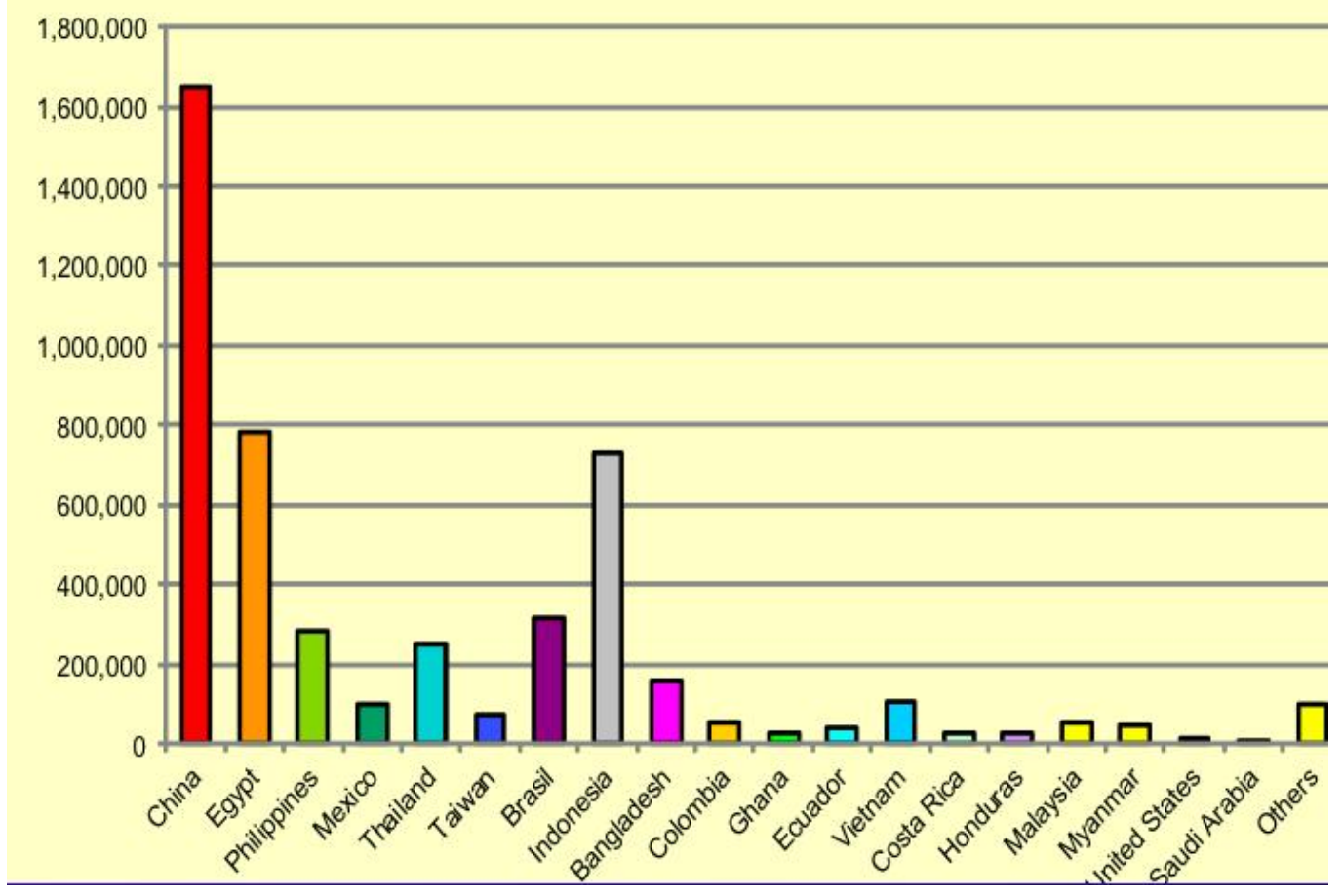

Fig. 5. World Tilapia production in 2015 (Fitzsimmons, 2016)

European seafoods into Russia, led to an increase of exports of tilapia and Pangasius from Vietnam to Russia. Thailand, Myanmar, and the Philippines consumed virtually all the tilapia grown in their countries. Bangladesh continued to increase its production at a tremendous rate. 2015 estimate is for more than $250,000 \mathrm{mt}$ in Bangladesh. Ecuador is the only country expecting production decreases as some tilapia farms have been converted to shrimp to take advantage of the increased shrimp prices. Global prices and demand have been remarkably smooth with only a slight decrease for a few months in late 2014 and early 2015 with large supplies coming from China. As production slacked from China, prices firmed again as demand had increased with the low prices. The diversity of production locations and methods has smoothed supplies and prices as more and more consumers take advantage of the high quality and consistent supply [53].

\section{DISEASES MEASURES}

AND

CONTROL

Diseases can often be avoided by maintaining a high quality environment and reducing handling stress. The major disease problems affecting Nile tilapia are included in the Table 1 [4].

\section{CONCLUSION}

Till a few past years, most of tilapia production was consumed locally, with Africa and Asia as developing countries. Now a day, there has been a growing acceptance and consumption of tilapias in non-traditional countries such as USA, Canada, Europe, Central and South America. Only USA it was reported that importation increased to about $75,000 \mathrm{mt}$ (whole fish equivalent), supplying nearly $90 \%$ of the country's demand. In view of the growing demand of this commodity, tilapia farming will persist to be an important source of animal protein, foreign exchange and employment opportunities in several countries. Ferdouse (2001) indicated that whether the tilapias that are being produced are for export or for domestic consumption, the quality of the fish and convenience are important factors that will influence the consumer demand, mostly in urban market in Southeast Asia. She claimed that in the well-heeled urban markets in this region (Hong Kong, Malaysia, Singapore and Thailand), good quality fish (without any foul or muddy odour) and expediency food (e.g. fish prepared into skinless fillets) will prolong to assists in tilapia sales for domestic consumption through retail outlets such as supermarkets. 


\section{COMPETING INTERESTS}

Authors have declared that no competing interests exist.

\section{REFERENCES}

1. Prabu E, Santhiya AAV. An overview of bioremediation towards aquaculture. Journal of Aquaculture in the Tropics. 2016;31(3-4):155.

2. FAO. The State of World Fisheries and Aquaculture 2010. Edited by FAO. Rome: FAO; 2010.

3. Scorvo Filho JD, Frascá-Scorvo CMD, Alves JMCGNA, Souza FRAD. A tilapicultura e seus insumos, relações econômicas. Revista Brasileira de Zootecnia; 2010.

4. FAO. The State of World Fisheries and Aquaculture 2012. FAO Fisheries and Aquaculture Department, Rome, Italy; 2012.

5. Subasinghe R, Soto D, Jia J. Global aquaculture and its role in sustainable development. Reviews in Aquaculture. 2009;1(1):2-9.

6. Bene $C$, Heck $S$. Fish and food security in Africa. NAGA, World Fish Center Quarterly. 2005;28(3-4):8-13.

7. Wang M, Lu M, Tilapia polyculture: A global review. Aquaculture Research. 2016;47(8):2363-2374.

8. Sosa ID, Adillo LAB, Ibanez LJ, Figueroa IA. Variability of tilapia (Oreochromis spp.) introduced in Mexico: Morphometric, meristic and genetic characters. Journal of Applied Ichthyology. 2005;20:7-10.

9. Ahsan ME, Wahab MA, Siddik MAB, Alam MA, Sharker MR, Nahar A. Impacts of Inclusion of Column Feeder Rohu (Labeo rohita) at different stocking densities on growth and production in freshwater prawn-finfish polyculture system. International Journal of Biological Research. 2013;1(2):48-54.

10. El-Sayed AFM. Tilapia culture. CABI; 2006.

11. Fitzsimmons K, Tilapia culture. In American Fisheries Society Symposium. 2005;2005(46):563-590.

12. Courtenay WR, Tilapias as non-indigenous species in the Americas: environmental, regulatory and legal issues. Tilapia Aquaculture in the Americas. 1997;1:1833.
13. Pullin RS, Eknath AE, Gjedrem $T$, Tayamen MM, Macaranas JM, Abella TA, The genetic improvement of farmed tilapias (GIFT) project: The story so far. Naga, The ICLARM Quarterly. 1991; 14(2):3-6.

14. Costa-Pierce BA, Doyle RW, Genetic identification and status of tilapia regional strains in southern California. Tilapia aquaculture in the Americas. 1997;1: $1-17$.

15. Costa-Pierce BA, Riedel R. Fisheries ecology of the tilapias in subtropical lakes of the United States. Tilapia aquaculture in the Americas. 2000;2:1-20.

16. Ramnarine IW, Singh D. Interaction between hormone concentration and water temperature on masculinization of tilapia fry. Tropical agriculture; 2005.

17. Gjedrem T, Genetic improvement for the development of efficient global aquaculture: A personal opinion review. Aquaculture. 2012;344:12-22.

18. Thys van den Audenaerde DFE. An annotated bibliography of tilapia (Pisces, Cichlidae). Musée royal de l'Afrique Centrale, Tervuren, Belgique; 1968.

19. Jhingran VG, Gopalakrishnan V. Fishery Resources and Environment Division Food and Agriculture Organization, Catalogue of cultivated aquatic organisms. Food and Agriculture Organization of the United Nations; 1974.

20. McAndrew BJ. Evolution, phylogenetic relationships and biogeography. In Tilapias: Biology and exploitation Springer Netherlands. 2000;1-32.

21. Rakocy JE. Integrating tilapia culture with vegetable hydroponics in recirculating systems. Tilapia Aquaculture in the Americas. 1997;1:163-184.

22. El-Sayed AFM. Effects of stocking density and feeding levels on growth and feed efficiency of Nile tilapia (Oreochromis niloticus) fry. Aquaculture Research. 2002; 33(8):621-626.

23. Altun T, Tekelioğlu N, Danabaş D, Tilapia culture and its problems in Turkey. EUJ Fisheries and Aqua. Sci. 2006;23(3-4): 473-478.

24. Fitzsimmons K. Prospect and potential for global production. Tilapia: Biology, Culture and Nutrition. Food Products Press, New York, USA. 2006;51-72.

25. Pullin R. Tilapia: Everyman's fish. Biologist. 1985;32:84-88. 
26. Gjoen HM. GIFT program continues. Distribution of fast-growing tilapia to expand. The Global Aquaculture Advocate. 2001;44.

27. Sugunan VV. Reservoir fisheries of India Daya Books. 1995;345.

28. Lakra WS, Singh AK, Ayyappan S. Fish introductions in India. In National Workshop on Fish Introductions in India: Status, Challenges, and Potentials (2006: National Bureau of Fish Genetic Resources); 2008.

29. Eknath AE, Bentsen HB, Ponzoni RW, Rye M, Nguyen NH, Thodesen J, Gjerde B, Genetic improvement of farmed tilapias: Composition and genetic parameters of a synthetic base population of Oreochromis niloticus for selective breeding. Aquaculture. 2007;273(1):1-14.

30. Bentsen HB, Eknath AE, Palada-de Vera MS, Danting JC, Bolivar HL, Reyes RA, Dionisio EE, Longalong FM, Circa AV, Tayamen MM, Gjerde B, Genetic improvement of farmed tilapias: growth performance in a complete diallel cross experiment with eight strains of Oreochromis niloticus. Aquaculture. 1998; 160(1):145-173.

31. Acosta BO, Gupta MV. The genetic improvement of farmed tilapias project: Impact and lessons learned. In Success stories in Asian aquaculture. Springer Netherlands. 2010;149-171.

32. ADB. Impact study on the development of genetically improved farmed tilapia and their dissemination in selected countries. Asian Development Bank Impact Evaluation Study. 2004;77. [REG 2004-20]

33. Yosef S. Rich food for poor people: Genetically improved tilapia in the Philippines. Intl Food Policy Res Inst. 2009;925.

34. Eknath AE, Hulata G. Use and exchange of genetic resources of Nile tilapia (Oreochromis niloticus). Reviews in Aquaculture. 2009;1(3-4):197-213.

35. Ponzoni RW, Khaw HL, Yee HY. GIFT: The story since leaving ICLARM (now known as the World Fish Center): Socioeconomic, access and benefit sharing and dissemination aspects; 2010.

36. Guerrero RD. Tilapia farming in the AsiaPacific region. In Tilapia farming in the 21st Century. Proceeding of the International Forum on Tilapia Farming in the 21st
Century (Tilapia Forum 2002), Philippines Fisheries Association, Inc., Los Banos, Laguna, Philippines. 2002;42-48.

37. Liao DS, Chen CW. Socio-economics and technical efficiency of tilapia production in Taiwan. 6th Asian Fisheries Forum Book of Abstracts; 2001.

38. Gutierrez-Wing MT, Malone RF. Biological filters in aquaculture: Trends and research directions for freshwater and marine applications. Aquacultural Engineering. 2006;34(3):163-171.

39. Hargreaves JA. Photosynthetic suspended-growth systems in aquaculture. Aquacultural Engineering. 2006;34(3):344363.

40. Crab R, Avnimelech Y, Defoirdt T, Bossier $P$, Verstraete $W$. Nitrogen removal techniques in aquaculture for a sustainable production. Aquaculture. 2007;270(1):1-14.

41. Avnimelech $\mathrm{Y}$. Biofloc technology. A practical guide book. The World Aquaculture Society, Baton Rouge. 2009; 182.

42. Naylor RL, Goldburg RJ, Primavera JH, Kautsky N, Beveridge MC, Clay J, Folke C, Lubchenco J, Mooney $\mathrm{H}$, Troell M. Effect of aquaculture on world fish supplies. Nature. 2000;405(6790):1017-1024.

43. Eding EH, Kamstra A, Verreth JAJ, Huisman EA, Klapwijk A. Design and operation of nitrifying trickling filters in recirculating aquaculture: $A$ review. Aquacultural Engineering. 2006;34(3):234260.

44. Chu CP, Lee DJ. Multiscale structures of biological flocs. Chemical Engineering Science. 2004;59(8):1875-1883.

45. Peron G, Mittaine JF, Le Gallic B. Where do fishmeal and fish oil products come from? An analysis of the conversion ratios in the global fishmeal industry. Marine Policy. 2010;34(4):815-820.

46. Crab R, Defoirdt T, Bossier P, Verstraete W. Biofloc technology in aquaculture: beneficial effects and future challenges. Aquaculture. 2012;356:351-356.

47. FAO. The State of World Fisheries and Aquaculture 2008. FAO, Rome; 2009.

48. Schneider O, Sereti V, Eding EH, Verreth JAJ. Analysis of nutrient flows in integrated intensive aquaculture systems. Aquacultural Engineering. 2005;32(3):379401.

49. Crab R. Bioflocs technology: an integrated system for the removal of nutrients and simultaneous production of feed in 
aquaculture (Doctoral dissertation, Ghent University); 2010.

50. Crab R, Kochva M, Verstraete W, Avnimelech $Y$. Bio-flocs technology application in over-wintering of tilapia. Aquacultural Engineering. 2009;40(3):105112.

51. De Schryver P, Crab R, Defoirdt T, Boon $\mathrm{N}$, Verstraete $\mathrm{W}$. The basics of bio-flocs technology: The added value for aquaculture. Aquaculture. 2008;277(3): 125-137.

52. Craig S, Helfrich LA. Understanding Fish Nutrition, Feeds and Feeding (Publication 420-256). Virginia Cooperative Extension, Yorktown (Virginia). 2002;4.

53. Fitzsimmons K. Supply and demand in global tilapia markets; 2015.

[Presentation: World. 2016]

(C) 2019 Prabu et al.; This is an Open Access article distributed under the terms of the Creative Commons Attribution License (http://creativecommons.org/licenses/by/4.0), which permits unrestricted use, distribution, and reproduction in any medium, provided the original work is properly cited.

Peer-review history:

The peer review history for this paper can be accessed here: http://www.sdiarticle3.com/review-history/35935 